\title{
Social Capital in Dealing the COVID-19 Pandemic
}

\author{
Ainur Rofieq, Susi Dian Rahayu, Sulastri Sulastri, Yanto Supriyatno, Aos \\ Kuswandi
}

Universitas Islam "45” Bekasi, Indonesia

*Corresponding author. Email: ainur.rofieq@unismabekasi.ac.id

\begin{abstract}
The purpose of this research is to describe the relationship between the village authority and the community in dealing with the COVID-19 epidemic. The notion of social capital is employed to assess the interactions that occur in this study. This study employs qualitative approaches. Data were gathered through interviews with village authorities and community leaders who served as informants. According to the study's findings, the government has done an outstanding job in prevention and management. Social capital includes values, trust, and social networks, as well as the formation of effective community groups and participation in pandemic response efforts. This social capital has the potential to solve social issues, particularly those connected to relationships.
\end{abstract}

Keywords: Social Capital, Village Community, Pandemic

\section{INTRODUCTION}

The global COVID-19 pandemic has had a significant impact on various aspects of life. Indonesia is one of the countries experiencing the impact of the COVID 19 Pandemic. Various efforts have been made by the Indonesian government to suppress the impact of the COVID 19 Pandemic. Among them are handling the impact of the COVID-19 pandemic, efforts made related to efforts to avoid the death rate of the population infected with the COVID-19 virus, as well as efforts to deal with socio-economic problems during the COVID-19 pandemic.

The alertness and anticipation efforts made by the Indonesian government in the early days of the spread of the COVID-19 virus were often questioned, many parties doubted the government because the government was often inconsistent with its policies. Various policies have been carried out by the Indonesian government to suppress the spike in the number of COVID 19, including the implementation of Large-Scale Social Restrictions (PSBB), which is stated in Government Regulation Number 21 of 2020 concerning Large-Scale Social Restrictions in the Context of Accelerating Handling of Corona Virus Disease 2019 (COVID-19). In addition to PSBB, other policies, namely the Enforcement of Restrictions on Community Activities, are contained in InstructionMinister of Home Affairs Number 03 of
2021 concerning the Enforcement of Restrictions on Micro-Based Community Activities and the Establishment of Command Posts for Handling Corona Virus Disease 2019 at the Village and SubDistrict Levels to Control the Spread of Corona Virus Disease.

This policy certainly has a significant impact on society. Especially for business actors, the limited business operations in the implementation of PPKM is a problem in itself. For workers, the impact of the PPKM policy is also felt. Many workers have had to be laid off or get a salary cut from the company due to the COVID-19 pandemic.

However, the Indonesian government has also provided various programs to communities affected by the COVID-19 pandemic, including Wage Subsidy Programs (BSU), Support of UMKM, Village Fund BLT, and other non-cash social programs. The provision of social assistance also encountered various obstacles. One of them is related to the community database of beneficiaries. Based on the findings in the field, some people receive more than one social assistance, but other people do not receive social assistance at all even though they need the assistance.

When people come to believe that society cannot address their issues on its own, the concept of social 
capital emerges. As a result, to achieve joint goals and interests, each member of the community must work together and cooperate effectively. The essence of social capital can be perceived in the process rather than the outcome [1]. Interpersonal interactions and social networks that provide people a feeling of identity shared duty, and collective accountability is referred to as social capital [2].

Based on social network ideals, standards, and beliefs, social capital is a system of values or norms shared among interrelated community groups. Putnam has three compelling reasons to believe this. The first is a social network that allows for cooperation and communication among community members, which can develop mutual trust. Second, trust has a favorable impact on social interactions. This is demonstrated by the fact that the interconnection of people in a social network who have mutual trust reinforces the norms surrounding the need to support one another. Third, the different accomplishments in this network that have been accomplished through cooperation in the past will encourage future cooperation [3].

Social trust in the Pantai Hurip Village government cannot be calculated, because the trust arises from the form or plan that has been implemented previously by the Pantai Hurip Village government. Every society has thoughts and views of each of the government, it can't be generalized. Therefore, the people of Pantai Hurip Village partially put their trust in government some are neutral. But it doesn't mean they don't trust the government, but they believe that they can protect themselves from the dangers of the COVID-19 virus. In addition, the community still respects and respects the efforts made by the government in handling the COVID 19 Pandemic. This study aims to examine the policies of the Pantai Hurip Village Government in handling the COVID-19 Virus in terms of the Social Capital Aspect.

\section{METHODOLOGY}

A qualitative research method with a case study methodology is used in this study. In this study, researchers employed observation techniques on what was being examined as well as interviews to collect data and answer the research questions.

\section{RESULTS AND DISCUSSIONS}

\subsection{Government Policy of Pantai Hurip Village in Handling the COVID-19 Pandemic}

The conceptual framework used to analyze the existence of social capital is divided into two dimensions: cognitive and structural. The cognitive dimension often referred to as the cultural dimension, is concerned with the values, attitudes, and beliefs that determine trust, solidarity, and reciprocity. These values, attitudes, and beliefs foster collaboration in society to achieve common goals. The second dimension is the structural dimension, which encompasses the structure, scope, and organizational structure, as well as local community institutions that accommodate and stimulate communal activities that benefit all members of the community [4].

The pandemic of COVID-19 has had a systemic influence on people's lives. The COVID-19 epidemic has had a huge influence not only on public health, but also on the economic, social, psychological, cultural, political, government, education, sports, religious, and other spheres. As a consequence, effective government actions are required to prevent and eliminate the COVID-19 virus.

Government efforts to limit the spread of the COVID-19 virus, such as remaining at home, social restrictions, physical restrictions, maintaining a safe distance, wearing masks, and others, will not be effective if the government does not produce adequate information. accurately relates to the COVID-19 virus's origins, spread, and treatment. The government, as a policymaker, must establish a social protection policy plan, which is far more significant. As far as the government's ability to develop a sound policy strategy for preventing and combating the COVID-19 virus in the population, as well as effective governance during the COVID-19 epidemic.

Based on the results of the study, the handling policy carried out by the Pantai Hurip Village government was to carry out activities to distribute masks, raids for motorists who did not wear masks, distribute vitamins, spray disinfectant regularly every month and are currently undergoing vaccination and have been running about $20 \%$. by implementing the Large-Scale Social Restriction (PSBB) policy, forming a Task Force Team within the Village Government, quarantine policies, and also PPKM (Implementation of Micro-Based Community Activity Restrictions), and always maintaining health protocols.

In addition, it is very necessary to have cooperation between stakeholders in handling the COVID 19 pandemic. Especially the cooperation of the village government and the community. Because every policy requires public participation to assist the process of running a policy. On the other hand, to 
bring order to the community with existing norms and regulations so that people do not act arbitrarily.

Based on the results of the study, one of the efforts to handle the COVID 19 pandemic in Pantai Hurip Village is the collaboration between the stakeholders involved. The elaboration between the village government, the health office, community organizations in the village, and the village community is an important factor in handling the COVID 19 pandemic in Pantai Hurip Village.

\subsection{Public Perceptions of the COVID-19 Handling Policy in terms of the Social Capital Aspect}

The behavior of the community greatly influences the course of policies implemented by the central and regional governments, especially during this COVID19 pandemic. Community involvement in Pantai Hurip Village can be seen from planning. The community represented by community leaders is fully involved in the planning process through meetings chaired by the Village Head.

Community involvement in development needs to be held through a forum that allows the community to participate directly, such as in the decision-making process about development programs at the local level. This community involvement will be realized until the program is completed [5]. Likewise with the handling of Covid-19 where the Covid-19 Task Force in Pantai Hurip Village is assisted by the local RT and RW who monitor the local community, and all coordinate with each other so that all programs can be carried out properly.

According to the study's findings, the community believes in the Pantai Hurip Village government's handling policy for preventing the spread of the COVID-19 virus. However, there are about $20 \%$ of people have not obeyed the policies implemented by the village government. The condition of Pantai Hurip Village is getting better day by day. People who obey the policies implemented by the village government are increasing.

So that currently Pantai Hurip Village is said to be a green zone area. There has never been any conflict in society during this pandemic. Because the people of Pantai Hurip Village understand and accept whatever conditions are happening, and the community focuses on prioritizing the safety of themselves and their families. There is a value of togetherness in society, especially in close neighbors. They will help as much as possible to families who are isolated or exposed. In addition, money and food assistance from the Village Government will be channeled to the exposed community. So people are not worried about the people who are being exposed.

One of the most essential things in dealing with the COVID-19 epidemic in Pantai Hurip Village is the village government's and the community's strong solidarity. They form tight bonds with one another, such as being excellent neighbors, to reduce the transmission of the COVID-19 virus. By not allowing tourists and other immigrants to come to the village area. If there are people who are exposed, then residents who are close neighbors to the houses that are exposed to help. In addition, residents also gave confidence to the COVID-19 task force team who were considered capable of handling the COVID-19 pandemic.

\section{CONCLUSION}

Based on the study's findings, it is possible to infer that the community's attitude toward government programs aimed at avoiding and dealing with the COVID-19 virus has been extensively adopted, with the result that the Pantai Hurip Village region is today in excellent condition. The Village Government has made efforts in handling the COVID-19 virus, the handling includes others distributed masks and vitamins, conducted raids, sprayed disinfectants, and vaccines. All policies imposed by the central government will be implemented by local or village governments and the handling is going well in collaboration with the Medical Team, BPD, youth organizations, volunteers, foundations, TNI, and Polri.

The existence of COVID-19 and the policies that emerged during this pandemic caused many perceptions in the community. However, it does not create conflict in the community. Relations between the community and the community with the government are well established. The value of togetherness contained in it can be seen very clearly. At least the community can implement social capital which includes social networks, norms, and trust and they respect each other to complete problems with maintaining the ties of friendship.

\section{AUTHORS' CONTRIBUTIONS}

Each author contributed to the completion and enrichment of the data and arguments while producing this work. 


\section{ACKNOWLEDGMENTS}

Our appreciation and gratitude to the village government for assistance in the collection of data and information for this work.

\section{REFERENCES}

[1]. Rusydan Fathy. Modal Sosial: Konsep, Inklusivitas dan Pemberdayaan Masyarakat. Jurnal Pemikiran Sosiologi. Vol 6 (1):2, 2019

[2]. Max Regus. Pentingnya Revitalisasi Modal Sosial Paska Pandemi COVID-19. Jurnal Kependudukan Indonesia. 11-14, 2020

[3]. Rusydi Syahra. Modal Sosial: Konsep dan Aplikasi. Jurnal Masyarakat dan Budaya. Vol. 5(1):6-9, 2003

[4]. Rusydi Syahra. Modal Sosial: Konsep dan Aplikasi. Jurnal Masyarakat dan Budaya. Vol. 5(1):6-9, 2003

[5]. T. Mardikanto \& P. Soebianto. Pemberdayaan Masyarakat dalam Perspektif Kebijakan Publik, Alfabeta, 2013 